\title{
Some Aspects of the Paradigm of Sanskrit Learning*
}

\author{
Nataliya Kanaeva \\ School of Philosophy \\ Department of Humanities \\ National Research University "Higher School of Economics" \\ Moscow, Russia \\ E-mail: nkanaeva@hse.ru
}

\begin{abstract}
The main issue of this article is the verification of the thesis on existence in Indian culture of a special paradigm of learning the paradigm of Sanskrit learning. The verification is made through the investigation of two aspects of the paradigm, close but not identical with the aspects of paradigm of Western epistemology and logic. The first (unchanged evaluation of knowledge as a necessary instrument for the implementation of main goals of human existence) contributed to the humanitarization of the system of traditional knowledge. The second aspect of Sanskrit paradigm is the limitations of reason's capabilities. Together with close relations in India between philosophy and religion this limitation determined the unfolding of logical argumentation simultaneously on two levels: logical and metaphysical, and the existence of paradoxical structures in Indian discourse.
\end{abstract}

Keywords—paradigm of Sanskrit learning; traditional Indian knowledge; paradoxes of Indian discourse

\section{INTRODUCTION}

Today the problems of traditional non-Western knowledge and its otherness have the grate interest not only for comparativists. Their investigation are extremely important for the implementation of the trend to the formation of a new style of philosophizing, which has been noticed by many philosophers, and its expression have been found in various projects: of transversal rationality, of transversal philosophy, of "intercultural philosophy", "world philosophies", etc.

Each historian of Indian philosophy, who explores texts in Sanskrit written by representatives of different religiousphilosophical systems (darśana), inevitably comes to the realization of two facts. The first one is that the texts of Indians are based on ideas about knowledge (its aims, producing of knowledge, its fixation and transmission) which are quite differ from the ideas on cognition, established firmly in Western philosophy. The second fact is that in the range of traditional Indian culture ${ }^{1}$ those ideas of philosophers belonging to different metaphysical positions have much more similarities, than they were between Indian

*The study is supported by Russian science Foundation grant "Indian philosophy in the context of the history of world philosophy: the problem of translation of meaning", project No. 16-18-10427.

i.e. Indian culture formed before Western colonization.

Philosophy born by traditional culture was traditional also. and Western conceptions. In spite of the discussions between them Indians views on knowledge had common frame. The frame was partly explicated in Sanskrit texts on epistemology and logic (hetu-vidyā - Sanskr. science of reasons, pramāna-vāda - Sanskr. theory of the instruments of cognition), but common logico-epistemological frame created the unity of Indian philosophical tradition. These common ideas about knowledge and cognition can be described by the Kuhn's term "paradigm of cognitive activity", as they "provide model problems and solutions" in the traditional philosophy [1].

Moreover, since in the history of Indian traditional culture darśanas were developed in collaboration with the specialized kinds of knowledge - the "sciences" (veda, vidyā, śāstra), - we can trace in the texts of religious-philosophical and scientific contents, by our opinion, the common paradigm of cognitive activity. As it is known, the core of Indian traditional knowledge recorded in a vast corpus of literature in Sanskrit that allows, firstly, to speak about the paradigm of Sanskrit learning (or scholarship) in a whole, and, secondly, to study the process of creation of the paradigm in a very broad historical and cultural context.

This paper focuses on two aspects of the paradigm of Sanskrit learning which determined non-scientific, existential character of traditional learning and the formation of paradoxical structures in Indian discourse.

\section{KNOWLEDGE AS AN EXISTENTIAL VALUE}

If in the history of Western epistemology knowledge mostly is seen as the goal, the ideal and one of the independent values of the cognitive activity, in the paradigm of Sanskrit learning knowledge (jñāna, vijñāna, pramā, pramiti) never have seen as an independent value. Knowledge is one of the main universals of traditional Indian culture, but only on the grounds that already in the earliest religious texts (mantra-saṃhitā, brāhmaṇas, āranyakas and upanișads), it is named as an essential instrument of any human activity. So, in "Chāndogyopanișat" the knowledge received through education (vijñāna), is called clearly as an instrument that allows the actor "to act as he wishes" (VII.1.5). In "Śatapatha Brāhmaṇa," dedicated to the annual ritual of Agnicayana (construction of the altar for the God of

\footnotetext{
yathākāmacāro bhavati.
} 
fire-Agni), knowledge is called the material for altars where the sacrifices to Agni were offered: "These fires (altars), in truth, are knowledge-built" (X. 5.3.12) [2]. Such image of knowledge as the material leaves no doubt of the need of knowledge for implementation of the most important activity in Ancient Indian society - ritualistic one, and of the much more value of activity by itself.

Subordination of knowledge for practical purposes in Vedic texts was the first model for the determination of value of knowledge, after then named model became obligatory: the purposes of compositions were always indicated in Sanskrit texts of darśanas and śāstras. So, "Nyāyasūtra" begins with demonstration of the practical utility of knowledge on Nyāya categories: "From the knowledge of categories they achieve the highest" ${ }^{3,}$ (NS I.1.1), i.e. liberation ${ }^{4}$ (NS I.1.2) [3]. "Vaiśeșika-sūtra" begins with the words: "Now, therefore, we shall explain Dharma" (VS I.1.1.); ; and "Dharma is that from which (results) the accomplishment of prosperity and the most excellent [existence]" (VS I.1.2) ${ }^{6}$ [4]. In "Arthaśāstra” by Kauțilya the author said about the aim of sciences: "Science is just the same with the help of that they know universal law and benefit" (Arthaśāstra I. 2. 9) [5]. In the Introduction "Paspaśāhnica"of Patañjali's "Mahābhāṣya" a list of goals are given (Pasp. 16-26): "To facilitate understanding of words. Without the help of grammar, it isn't easy to understand the words" ; and "Knowledge of the right words is Dharma, knowledge of the wrong words is adharma"9 [6].

In Western culture the practical usefulness of knowledge begins especially appreciated from the Modernity, with its pathos of progress, Enlightenment and the slogan "Knowledge is power". During previous historical epochs on the West the ideal of a contemplative theoretical knowledge dominated, which was installed in the "Metaphysics" of Aristotle. The philosopher said, that we esteem the sensual knowledge for its own sake, not only with a view to action, and then he valued philosophy - the most abstract and useless knowledge - as the best [7]. Such contemplative ideal have not contributed to the need for authors to justify the practical utility of their compositions every time.

It is significant that the choice of the practical aim of knowledge was correlated with religious and ethical teaching on the life goals (purusāantha), adopted in the worldview system an author adhered to, and the choice was made with the account of purposes' stratification. Above we have given examples of Orthodox writings for proving of this thesis: from "Nyāya-sūtras", "Vaiśeșika-sūtras", "Arthaśāstra"by Kauțilya and Patañjali's "Mahābhāșya", where the highest, religio-metaphysical aims - liberation (apavarga) and universal law (Dharma) - were named. In Buddhist and Jain writings too, the purpose of knowledge is called liberation

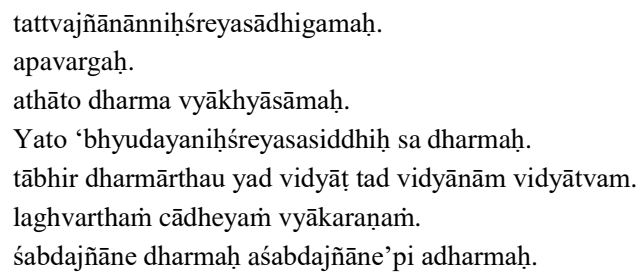

(mokșa, mukti) from the cycle of birth and death. For example, in his commentary to Buddhist "Compendium of Categories" Kamalaśîla said: "by diligent studies of sciences [even] not able human being gradually leave samsara and then reach liberation" ${ }^{10}$ [8]. Jain Umāsvāti in his "Tattvārthaadhigama-sūtrā" called knowledge together with right vision and right behavior "the path of liberation"11 [9]. In those compositions, where, as in "Carakasamphitā", the practical aims of knowledge in everyday life are indicated, the aims are subordinated to the same final goal of liberation.

A bunch of "knowledge-practical purpose" didn't become an obstacle to the appearance in Sanskrit literature bulky scholastic works which have been benefiting only for their authors. But the model of the justification of knowledge value through the demonstration of its need for an achievement of vital objectives was saved. This model retained in the nucleus of Indian culture the unbreakable connection between knowledge and its aims. At all times Indians saw: all knowledge is necessary for life! Life has many goals, material and sacred, achievable in this material world and in that, higher, immaterial world. They are real, and all knowledge is necessary for their achievement. In India traditional knowledge was orientated to purposes of human Being, this orientation determined its non-scientific, existential character in the sense of permanent interest to human existence, human experience and ways of speaking about Being. Thus, the bunch "knowledge - practical goal" preserved the unity of human Being, prevented "oblivion of Being" (M. Heidegger), the isolation in it and the hypostatization of its material dimension, as have happened in Western culture. If Western philosophy in the twentieth century had "return to the problem of Being," in Indian philosophy Being never dropped off the mind of the thinkers.

\section{THE PARADOXES OF INDIAN DISCOURSE}

The second important component of the paradigm of Sanskrit learning is the status of knowledge received by means of reasoning, which we call "rational", and in Sanskrit literature it is called "inference" (anumāna), or the product of mental construction (kalpanā). It is well known that in Western culture rational knowledge was always considered as the highest form of knowledge, and in India it was placed below the knowledge gained through the super-mind powers: intuition of a yogi (yogi-pratyakșa), telepathy (manahparyāya), clairvoyance (avadhi-jñāna), omniscience (kevalajñāna). Anumāna was put below even perceptual knowledge, as it was dependent on it, followed it. The etymology of the term anumāna (Sanskr. anu + mā - subsequent measurement) indicates its dependent character. As the results of this attitude, potentials of rational knowledge in obtaining and justification of knowledge were restricted, and in philosophical discourse paradoxical forms of reasoning (from the perspective of Western researchers) appeared. But these paradoxes are not visible from traditional Indian discourse. This situation leads the researchers to the

10 tasyāścāvidyāyā yogābhyāsādasamarthatarata makṣaṇotpādakrameṇa ...bandhamokṣavyavasthā yuktimatī .

11 samyagdarśanajñāna cāritrāṇi mokṣamārgah. 
assumption that in Sanskrit scholarship the discourse was subordinated to special rules, not always explicit.

A source of paradoxes is Indian theory of debate (tarkavidyā, hetu-vidyā, nyāya-śāstra). In Western culture theory of polemics is an essential and universal tool for rational justification of knowledge. In India theory of polemics also sets norms and regulates the situation of clash of opinions, suggests means either for their proving or disproving. In the texts of the middle of the First millennium BC theory of polemics is named among the obligatory disciplines for brahmanas and the rulers; the fact tells about its antiquity and about its great importance. And we expect to find in the polemical writings some foreseeable set of rules of debates, which became the results of a long history and the shortest paths to victory, i.e. to the proving the truth of their own thesis, and to the refutation of others. We really find rules in the Indian theory of polemics, but we don't find "the shortest way to victory", and we don't find generally accepted rules: each school has its own set of rules, normalizing a rather long process of discussion. It's significant that there is no requirement similar to the Cartesian rule, "to include in reasoning only what appears to the mind clearly and distinctly," as well as no requirement of setting the objective truth at the end of the debate.

But we find such fixed structures of reasoning as catușkoți (four-part negation), used mighty "bull of controversy" (tarka-pungava) Buddhist-Mādhyamika Nāgārjuna (II-III centuries), which leads to the conclusion about the fundamental impossibility of discursive thought, or we find the Jains' rules of debate that defines actually infinite procedure of justification of true statements. In the book of the skeptic Jayarāśi Bhatṭa "Tattvopaplavasimha" we see a consistent analysis and the refutations of the concepts of all instruments of valid cognition (pramāṇa), but in the same text the need to distinguish between pramānas are recognized: "[If we use instruments of valid cognition, without specifying them], then [we could] speak about the existence of color in the soul and the existence of pleasure in a pot and so on"12 [10]. Each of the disputants wanted to pull opponents to his side, and according to their texts, they all were the winners. But different philosophical systems not only survived for centuries, but they were strengthened in the course of the debate.

For each Western researcher at first glance such kind of debates, when logic is used for the destruction of discursive thought or leads the substantiation of truth in the bad infinity, seems absurd. If it is impossible to prove the truth by discursive methods, then what for the rules of debate serve in India?

A deeper understanding of the writings of Indian thinkers leads us to the conclusion that the Indian theory of the controversy is also addressed to discursive thinking, but to the thinking which never was absolutized, and in the practice of dispute its aims were understood differently a bit than in the Western one. By my mind, an application of techniques

\footnotetext{
12 atha...na ca...vyavahārah kriyate tadātmani rūpāstitva vyavahāro
} ghațādau ca sukhāstitva vyavahāraḥ pravartayitavyaḥ. of polemics in the context of religious and philosophical discussions determined the presence in the debates and in the theory of argumentation at the same time two meanings, or two levels: logical, directly expressed in the discussions, and religious-philosophical (or metaphysical) meaning, which often wasn't expressed, but which "worked" there "by default". This metaphysical sense can be reconstructed from the content of the thesis and of the arguments used by disputants, and also from the cultural context of the debates of philosophers. The logical aim of discussions determined its logical sense, and the theory taught with the rules of debate to prove and disprove consistently separate, private statements. Metaphysical sense of the theory was constructed by metaphysical purposes of discussions: theory of debates taught how to defend the positions of its own school, which couldn't be justified rationally, because they were beyond the scope of accessibility for the senses (indriya) and thinking - in all concepts of different darśanas (concepts of buddhi, citta or vijñāna). The use of logical reasoning demonstrated the fundamental weakness of the opponent. The demonstration could convince him to take along with the rational part of a stronger metaphysical position of its superrational part.

A lot of facts indicate the presence of these two meanings of discussions and theory of debates. First is the presence of two goals of the controversy noted by some researchers. One example is in the article by J. Ganeri dedicated to the Buddhist polemical text "Kathāvatthu", in which the author said about a distinction he saw: "a distinction between the global aim of the dialog as a whole"- rehearse considerations upon an issue of dispute - "and the local aim of each participant - to advocate the stance he adopt" [11]. The first aim correlates with my logical aim, and the second one with my metaphysical aim. The Buddhists forced the opponents to refuse from their attitude by logical means, by showing of contradictions between the consequences of their thesis or between a thesis and the consequences. The demonstration of contradiction constitutes the logical meaning of argumentation. The metaphysical meaning consists in indirect proof of their thesis by way of denial of alien thesis. In the course of debate the Buddhists preferred don't formulate their thesis explicitly.

Secondly, two named senses stem from the ideas of the two levels of reality (the higher - pāramārthika, and the lower - vyavāharika) corresponds to the two kinds of truth: the higher - pāramārthika satya, and the lower - vyavāharika satya, which established in Indian philosophy. Discursive thinking and the senses may give only a lower truth. Polemics with the opponents, who have a vision of the fullness of Being, that includes both the lower and the higher levels, can be fulfilled only on the lowest level.

The presence of other, non-logical (and hence metaphysical) sense of theory of debate gives, thirdly, the permissibility of non-logical techniques, contributing to the victory in the dispute. Thus, in "Sthānānigasūtra", one of the 11 āgamas of Jaina-śvetāmbara Canon, there is a section on the debate - "Vivāda-pāda", 6.67; there all sorts of quibbles are allowed. E. Solomon appreciated these methods of debate as "kind of tricks." And the commentator of the sutras 
Abhayadeva called them "jalpa" - wrangling [12]. In "Vivāda-pāda" six methods of controversy (vivāda) are named, and none of them defined as a way of establishing objective truth ${ }^{13}$. In the Western theory of debate various tricks are described also, but they are qualified as "illogical", and the logicians admit them as not leading to objective truth; their purpose is to persuade audiences to believe in the truth of opinions.

The metaphysical goal to convince an opponent to abandon his theses is visible, in the fourth, in two Jain's concepts: syādvāda (the method of "affirmation of possible", or sevenfold paralogism) and nayavāda (the method of "points of view"). They can be found at the compositions of authoritative thinkers: in "Daśavaikālika-nirukti" of Bhadrabāhu-senior (II century BC), in the texts of Umāsvāti (III-IV centuries) and Kundakunda (III-IV centuries). Often Jains interpret them as the rules of knowledge, but the analysis of the context of their using demonstrates their polemical character and the fact that they are the forms of refutation, not the forms of proof. Called dialectical methods are closely linked with the ontological concept of diversity, non-uniformity of reality (anekantāvāda). From the Jain's point of view, "It claims the indeterminateness of reality, its knowledge and its verbal expression. If reality is infinitely manifold, logically there must be infinite ways of intellectually cognizing it and verbally expressing its infinite aspects" [13]. Non-Jain philosophers cognize these individual temporal characteristics of reality, but they absolutize their relative knowledge, see it as absolute truth. Relative truths are dangerous because, being incomplete, they are passed to other people, and they may be the causes of conflict. Therefore, relative truths must be refuted by syādvāda and nayavāda methods.

Both Jain methods are not "frontal attack" on the opponents. They contain rules for multi-stage procedure for the consideration of opponents' theses. As the subject of judgment has a lot of sides, then each side can be viewed by passing it through the form of the sevenfold paralogism with the stating of seven propositions in accordance with fixed samples, as it in "Pañcāstikāyasāra", 14, of Kundakunda. He said, that "substance can be considered in accordance with the seven aspects: "Probably it is so", "[probably] is not so", "[probably] it is so and not so", "[probably] it is indescribable" and three more [option]" [14]. For each proposition it is necessary to find out the conditions of its truth.

The resulting "relative truths" can also be seen from different "points of view": as statements that describe

13 They are: osakkaittā - a departure from the subject of discussion when it is not possible to give an immediate response (in order to gain time for thinking); usakkaittā - a dispute with obviously less well prepared opponent; anulomaittā - prior to the beginning of the debate declination of the jury or opponent to their side by the acceptance of his thesis; padilomaittā - being confident in their abilities, proponent may put yourself in front of a jury, or opponents in a negative light, and then win; bhaittā to begin the debate after the expectations of the jury and thus (make the jury to feel shame) to influence their decisions; bhelaittā - start the debate after achieving consensus of the jury members or after setting them against an opponent. generic and specific characteristics of the subject of judgment, as propositions about a role of the subject in everyday practice, about its phenomenon at the moment, about its designations, and the etymology of its designations, and how designations correspond to his essence, etc. That is, the Jain theory of argumentation requires convince an opponent that he is not fundamentally wrong, but he is right, though he is right partially, relatively.

The discussion with opponents could last long, because the number of points of view and their kinds varies in different texts from 700 to 800 . If Umāsvāti have listed the five main "points of view" (i.e, "non-separating," "giving knowledge of the generic quality," "point of view of everyday practice" and "phenomenal" or "[method] to study of verbal designations," "the etymological [viewpoint]," "the method of signification in compliance with reality") ${ }^{14}$ and five subspecies for two of them, thus, the eight "points of view" in all [15]. Then Vinaya Vijaya (1613-1681) in his "Naya-karnikā" dropped a note on the existence of hundreds of subspecies of each naya (NK 20) [16]. So, if we apply Vinaya Vijaya's remark to the list of nayas by Umāsvāti, then there will be 800 "points of view". But if we follow the tradition of Śvetāmbara Canon, in their treatises "Sthānāṅga," "Anuyogadvāra," and etc. established the existence of seven nayas, then "points of view" in all will be 700. Multiply them with seven steps of "sevenfold paralogism," we receive from 4900 to 6400 potential steps for substantiation of a partial truth of opponent thesis.

So, if syādvāda and nayavāda would be the methods of cognitive activity, they are completely ineffective, because they don't allow receive an ultimate truth (the truth is on the other, the transcendental level of reality). But as methods of refutation they are quite effective: during the long debate, the opponent would hardly be able to keep the perfection of his teaching, and it is quite difficult to refute the Jains because their thesis is not formulated explicitly.

Obviously, for Jains, the purpose of the debate could not be direct justification for their thesis, which is not even formulated. For them a goal was a refutation of metaphysical position of opponents through the demonstration of relativity of their understanding of reality.

Metaphysical sense of discussions can be seen also in the Buddhist theory of argumentation which is presented in many canonical and near-canonical writings, for example in one of the canonical texts, "Kathāvatthuppakaraṇa" by Moggaliputta Tissa (255 BC). There theravāda teachings are settled down by the method vādayutti (non-eristic dialogue). In the text the rules of the method didn't named and explained. Buddhists didn't have need to explicate them, as they knew them by heart. In the commentary to "Kathāvatthu" they are partly revealed to the non-Buddhist reader.

Each step of the controversy (sub-dialog) begins with the establishment of the thesis, clarifying the main thesis in one of the eight relations: 1) $\mathrm{A}$ is $\mathrm{B}$ ? 2) $\mathrm{A}$ is not $\mathrm{B}$ ? 3) $\mathrm{A}$ is

14 Naigamasamigrahavyavahāraṛjusūtraśabdasamabhirūọhaivamibhūt 
everywhere B? 4) A is always B? 5) A all have B? 6) A all is not $B$ ? 7) $A$ is not always B? 8) $A$ all is not $B$ ? [17]. In "Kathāvatthu" the steps called "eight refutations" [18]. The form of discussions in "Kathāvatthu" is looks like Jain's syādvāda very much: the Buddhists enumerate different possibilities of truthful propositions, but with another, universal quantifier. With mind the fact that every sub-dialog is divided into 5 stages and includes the procedures called: anuloma - "the way forward," patikamma - "the way back," niggaha - refutation, upanayana - application, and niggamana - conclusion, a clarification of the main thesis involves at least 40 interrogative statements, which are offered by proponent to respondent. The respondent when he answers either positively or negatively, opens its theoretical position, and then theravādin can see the contradictions in respondent's teaching.

If the respondent recognizes the contradiction, he will abandon one of the conflicting claims. This abandonment is the main purpose of anuloma and of the other parts of the discussion. Thus, the main goal of Buddhist dialectics looks like the Jain's one: not to prove own thesis directly, but to point at invalidity of the opponent's thesis. But if for Jains invalid proposition is the one which is truthful relatively, for Buddhists invalid proposition is the one which leads to contradictions. The Buddhists tried to force the opponent to abandon some of the contradictory consequences, and in the future - to refuse from their thesis.

\section{CONCLUSION}

Examples of authoritative Sanskrit texts confirm the thesis of the author about the existence in Indian culture special paradigm of learning - paradigm of Sanskrit learning with two aspects, the two mental devices, close but not identical with the aspects of paradigm of Western epistemology and logic. The first is unchanged evaluation of knowledge as a necessary instrument for the implementation of main goals of human existence. This mental device contributed to the humanitarization of the system of traditional knowledge, - I mean the accumulation of knowledge on human life, the functions of body and of human psyche. The second aspect of the paradigm of Sanskrit learning is associated with the attitude on rational abilities of the person. Indian philosophers did not absolutize mind, they acknowledged the limitations of its capabilities. Together with close relations in India between philosophy and religion this limitation determined the unfolding of logical argumentation simultaneously on two levels: logical and metaphysical. But for Western riders such kind of argumentation looks like using of rational methods for the destruction of discursive thinking.

\section{REFERENCES}

[1] Th. S. Kuhn, The Structure of Scientific Revolutions, 2nd ed., in International Encyclopedia of Unified Science, In 2 Vols., Vol. II, № 2, London-Chicago: The University of Chicago, 1970. P. VIII.

[2] The Śatapatha Brāhmaṇa, According to the text of the Mādhyandina school, Part IV, Books VIII, IX and X, at Sacred Books of the East, Vol. 43, J. Eggeling tr., Oxford: the Clarendon Press, 1897, p. 380.
[3] Gautama, The Nyāya-sūtras with Vātsyāyana's Bhāṣya and Uddyotakara's Vārttika, in "Indian Thought series", tr. into Engl. with copious Notes by G. Jha. In 4 vols. Allahabad, 1915-1919.

[4] The Vaiśesika Sūtras of Kanāda, Sanskr. end Engl. tr. by V. Sinha, 2nd ed., in The Sacred Books of the Hindus, Vol. VI, Allahabad: Vijaya Press.

[5] Kautilya, Arthaśāstra, A critical Ed. with a Glossary by R.P. Kangle Bombay: University of Bombay, 1969.

[6] The Vyākaraṇa-Mahābhāṣya: Paspaśāhnika, Introduc., Text, Transl and Notes by S.D. Joshi and J.A.F. Roodbergen, Poona: Poona University Press, 1986, pp. 34, 43.

[7] Aristotle. Aristotle in 23 Volumes, Vols.17, 18, tr. by H. Tredennick, G.C. Armstrong, Cambridge, MA: Harvard University Press; 1989. A980a, A983a.

[8] Śāntarakșita, Tattvasaṃgraha, with the comment. Pañjikā of Shrī Kamalaśîla, in 2 vols., ed. by E. Krșnāmācārya, with a Foreword by B Bhattacharyya, Baroda, 1926. Pañ. to kar. I.75.

[9] Umāsvāti, Tattvārtha-adhigama-sūtrā , ed. with Engl. tr. by J.I Jaini, Arrah, 1920, in Sacred Books of the Jains, Vol. 2. Sū I.1.

[10] Jayarāśi Bhatta's Tattvopaplavasimha: An Introduction, Sanskrit Text, English Translation \& Notes, tr. by E. Solomon, Delhi: Parimal Publications. 2010, p. 2.

[11] J. Ganeri, "Argumentation, Dialogue and the Kathāvatthu”, Journal of Indian Philosophy, 2001, Vol. 29, pp. 485-493, p. 486.

[12] E.A. Solomon, Indian Dialectics: Methods of Philosophical Discussion, in 2 vols., Ahmedabad.: B.J. Institute of Learning and Research, Gujarat Vidya Sabha, 1976-1978. Vol. 1, p. 46.

[13] S.M. Shaha, "Anekānta and the Problem of Meaning", Annals of the Bhandarkar Oriental Research Institute, Vol. 67, № 1 / 4, 1986, pp. 139-145.

[14] Kundakunda, Pañcāstikāya-sāra, tr. from Prakrit into Russin, in N.A Jeleznova, The Teaching of Kundakunda in the Philosophicoreligious Tradition of Jainizm. M.: Oriental Literature Publishers of the RAS, 2005, pp. 237-267.

[15] Umāsvāti, Tattvārtha-adhigama-sūtrā. Sū I. 33.

[16] Vinayavijaya. Nayakarṇikā // The Naya-karnika. A Work on Jaina Logic by Sri Vinaya Vijaya Maharaj // Ed. with Introduction, English Translation and critical notes by Mohanlal D. Desai. Arrah (India), 1915

[17] J. Ganeri, Argumentation, Dialogue and the Kathāvatthu, p. 486.

[18] Points of Controversy (Kathāvatthu), tr. by S.Z. Aung \& C.A.F. Rhys Davids, Bristol, London: Pāli Text Society, 1915, p. 8. 